Original Research Article

\title{
Prescription auditing and observational study in a tertiary care hospital
}

\author{
Manju Gari, Manisha Varshney*, Shreya Lal
}

Department of Pharmacology and Therapeutics, Rajendra Institute of Medical Sciences, Ranchi, Jharkhand, India

Received: 18 July 2019

Revised: 20 August 2019

Accepted: 21 August 2019

*Correspondence to:

Dr. Manisha Varshney, Email: drmanishavarshney @ gmail.com

Copyright: (C) the author(s), publisher and licensee Medip Academy. This is an openaccess article distributed under the terms of the Creative Commons Attribution NonCommercial License, which permits unrestricted noncommercial use, distribution, and reproduction in any medium, provided the original work is properly cited.

\begin{abstract}
Background: Prescription is an important document written by a doctor which if not written properly can lead to various problems such as adverse drug reactions in patients, incompatibility to follow the instructions to take timely medications and sometimes over dosage due to improper prescription can even lead to death of the patient.

Methods: This prospective observational cross-sectional study was conducted over a period of 6 months. The study was conducted in Rajendra Institute of Medical Sciences, Ranchi. Various prescriptions were collected from outpatient care facilities of a tertiary care hospital. Results were analyzed and assessed on 150 prescriptions collected.

Results: Total 150 prescriptions were evaluated out of which $49.3 \%$ were males and $50.7 \%$ were females. Various parameters were assessed during the study which showed that there is still a scope of improvement in prescribing patterns in areas of writing complete prescriptions, prescribing generic medications and mentioning drug dosage forms as well as time of administration in each prescription.

Conclusions: The results showed there is still a scope of improvement in writing practices of prescription. The doctor should incur the habit of writing generic names of drug in every prescription. They should adopt proper handwriting skills and no mistakes should be done in a prescription. A good prescription written by a doctor will help in legible practice and will also be very helpful in patient's care.
\end{abstract}

Keywords: Prescription, Auditing, Tertiary care teaching hospital, Generic drugs

There are various advantages of a prescription audit which are: promoting good practice among doctors, minimizing errors in a prescription, providing utmost care to the patient, maintaining the standards of professional practice and finally restoration of rational use of drugs. A proper rationale must be followed in prescribing medications to the patient. Examples of irrational use of medicines include: poly-pharmacy, inadequate dosage, and use of antibiotics even for non-bacterial infections, excessive use of injections when oral forms can be given, self-medication and non-compliance to standard dosing regimens. ${ }^{2}$

Different studies conducted on the prescription auditing in different parts of the world produce their own database 
for the future comparative studies. ${ }^{3}$ So, an observational study was conducted on the prescription auditing from various departments of a tertiary care teaching hospital.

\section{METHODS}

A prospective observational cross-sectional study was carried out in a tertiary care teaching hospital over a period of 6 months at Rajendra Institute of Medical Sciences, Ranchi. The prescriptions were collected from various departments (Medicine, Neurology, Ortho, Paediatrics, Skin, Surgery) and analysis was done at RIMS, Ranchi. Study was conducted during $10^{\text {th }}$ march 2018 to $10^{\text {th }}$ august 2018 . The study was approved by the Institutional Ethics Committee.

The study population consisted of all patients who visited the various departments of RIMS and for whom medicines were prescribed during the study period.

Critically ill indoor patients and prescriptions including only investigational advice were excluded.

Following parameters were analysed in prescription auditing. ${ }^{4}$

- Patient details: Patient name, sex, body weight, date of prescription received.

- Description of drug: Drug dose, dosage form, generic name, brand name, duration of treatment, time of administration, average no. of drugs per prescription.

- Clinical diagnosis.

- Doctor's signature.

Data was analysed by statistical tools.

\section{RESULTS}

In this study, a total of 150 prescriptions were evaluated over a period of six months (Table 1). Out of 150 samples analysed, $49.3 \%$ were males and $50.7 \%$ were females. Patient name and sex were mentioned properly in all the prescriptions along with date of prescription received. Body weight of the patient was not mentioned in any of the prescriptions. Drug dose was mentioned in $93.3 \%$ of prescriptions while drug dosage form was mentioned in $96.7 \%$ of prescriptions. Few of the prescription had the name of doctors mentioned but without their signatures. Only $5.3 \%$ of the prescriptions contained generic name of the drugs while $96.7 \%$ contained brand name of the drug. Duration of treatment was mentioned in $74.7 \%$ of the prescriptions while time of administration of drug was mentioned in $28.7 \%$ of the prescriptions. Average number of drugs prescribed per prescription was 3.8. Few of the prescriptions had spelling mistakes and unclear handwriting.
Table 1: Evaluation of various parameters in a prescription.

\begin{tabular}{|lll|}
\hline $\begin{array}{l}\text { Parameters of } \\
\text { prescription audit }\end{array}$ & $\begin{array}{l}\text { Yes } \\
\text { (mentioned) }\end{array}$ & $\begin{array}{l}\text { No (not } \\
\text { mentioned) }\end{array}$ \\
\hline Patient name & 150 & 0 \\
\hline Patient sex & 150 & 0 \\
\hline Patient body weight & 0 & 150 \\
\hline $\begin{array}{l}\text { Date of prescription } \\
\text { received }\end{array}$ & 150 & 0 \\
\hline $\begin{array}{l}\text { Clinical diagnosis } \\
\text { mentioned }\end{array}$ & 66 & 84 \\
\hline Drug dose & 140 & 10 \\
\hline Drug dosage form & 145 & 5 \\
\hline Drug generic name & 8 & 142 \\
\hline Drug brand name & 145 & 5 \\
\hline $\begin{array}{l}\text { Duration of treatment } \\
\text { mentioned }\end{array}$ & 112 & 38 \\
\hline $\begin{array}{l}\text { Time of administration } \\
\text { mentioned }\end{array}$ & 43 & 107 \\
\hline Total counts & 1109 & 541 \\
\hline \% of total counts & $67.21 \%$ & $32.79 \%$ \\
\hline
\end{tabular}

Total counts over all $=150 * 11=1650$.

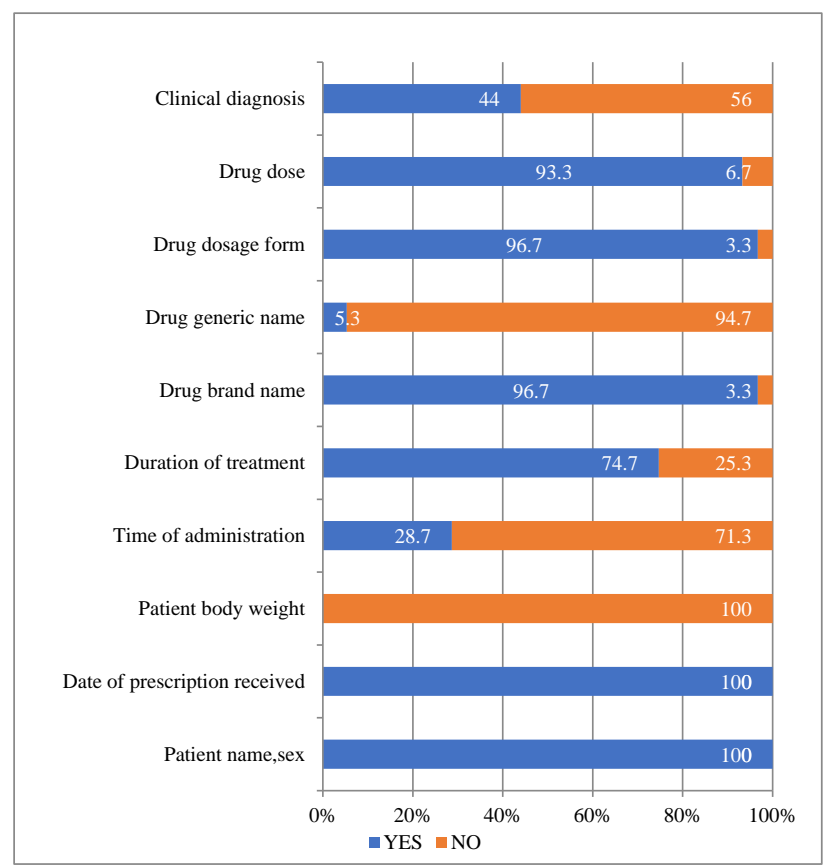

Figure 1: Study of prescription audit parameters.

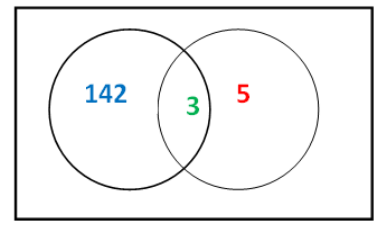

Drug brand name $=145$

Drug generic name $=8$

Both generic and brand name $=3$

Figure 2: Venn diagram depicting the number of prescriptions containing only drug brand name, only drug generic name and those containing both generic and brand names. 


\section{DISCUSSION}

In this study, $96.7 \%$ prescriptions did not contain even a single drug prescribed in its generic name (Figure 1). None of the prescriptions were mentioned with body weight of the patients, not even the prescriptions collected from paediatrics department.

A similar study highlights the practice of poly-pharmacy, low usage of generic drugs, injudicious usage of antibiotics and injections and low usage of drugs from essential drugs list in other parts of this region in India. ${ }^{5}$ Total four parameters were assessed in 150 prescriptions including patient details, description of drug, clinical diagnosis and doctor's signature.

Out of 150 prescriptions analysed, each prescription contained the name and sex of the patient as well as date of the prescription received. In none of the prescription, body weight of the patient was mentioned. Dose of the drug was mentioned in 140 of the prescriptions while dosage form was mentioned in 145 prescriptions. Clinical diagnosis was mentioned only in 44 prescriptions out of 150 while rest prescriptions only contained the presenting complaints of the patient. Medical history of the patients was mentioned only in few of the prescriptions while in many of them, history of the patient was never taken at all. Duration of treatment of drug was mentioned in 112 prescriptions. Time of administration of drug was mentioned only in 43 prescriptions. Generic name of the drug was mentioned only in 8 of the prescriptions collected while brand name was mentioned in 145 prescriptions. Both generic name and brand name of the drug were mentioned only in 3 prescriptions (Figure 2).

The low selection of generic drugs were similar to study conducted by Sandoz et al, in which it was $6 \% .{ }^{6}$ However studies conducted by Junid et al, in Malaysia (45.2\%) and Nwidu et al, in Nigeria (37.4\%) have documented higher prescribing of drugs by generic name. ${ }^{7,8}$ Drugs should be prescribed by generic name as it avoids duplication of constituents of drugs and provides cost effective drug therapy.

Average number of drugs prescribed per prescription was 3.8. Shankar et al reported in their study number of drugs per prescription 4.3. ${ }^{9}$ About $15 \%$ of the prescription contained 6 or more drugs which was found mostly from prescription obtained from Neurology department $(8.4 \%)$. The dosage form prescribed was mostly tablet form $(88.1 \%)$ while topical form was prescribed only in $15.2 \%$.

The present study clearly indicates there is a great need of modifications in prescription writing. Doctors are required to prescribe generic medications to patients, this can be achieved with the help of educational circulars. Guidelines for rational use of drugs must be provided to every health facility. ${ }^{10}$ Proper guideline for writing legible prescriptions should be made available in all health facilities and strict orders should be given to every medical professional to abide by these guidelines. Various workshops and seminars must be conducted in the institution to provide medical knowledge about rationality of drugs, polypharmacy, guidelines for treatment and random check of prescription must be done from time to time to keep a check on proper guidelines being followed by doctors. ${ }^{11}$

\section{CONCLUSION}

Prescription auditing gives us a current picture of prescribing practices in a tertiary care hospital setting. This observation study shows there is a great need of improvement in prescribing practices in the areas of writing detailed prescription including the dose and the dosage form of the drug, time of administration of the drug, reducing the no. of drugs in a prescription thus reducing the practice of polypharmacy. There is a great need of mentioning generic name of drugs in each prescription with a must signature as well as name of the doctor and his registration number. Prescription audit is an important tool in improving the quality of patient care. A proper action plan must be created in order to improve the patient care, and more focus should be done on rationality of drugs.

\section{Funding: No funding sources}

Conflict of interest: None declared

Ethical approval: The study was approved by the Institutional Ethics Committee

\section{REFERENCES}

1. Kandula P, Rao S, Sangeetha K, Reddy Y \&Gudi S. A study of prescription audit in outpatient department of a tertiary care teaching hospital in India: an observational study. J Drug Delivery Therap. 2017;7(3):92-7.

2. Hogerzeil HV. Promoting rational prescribing: an international perspective. $\mathrm{Br} \mathrm{J}$ Clin Pharmacol. 1995;39(1):1-6.

3. Bandyopadhyay D, Banerjee CN, Chattopadhyay S, Singha P. A study of prescription auditing in a Tertiary Care Teaching Hospital of Eastern India. J Drug Deliv Ther. 2014;4(1):140-9.

4. Panayappan L, Jose JM, Joseph JG, Jayapal K, Saju S, Kumar K. Prescription audit and prescribing indicators: a review. J Bio Innov. 2017;6(4):542-7.

5. Gopalakrishnan S, Ganeshkumar P, Katta A. Assessment of prescribing practices among urban and rural general practitioners in Tamil Nadu. Indian $\mathbf{J}$ Pharmacol. 2013;45(3):252-7.

6. Sandozi T, Naushe F. Drug utilization study in ischemic heart diseases associated with diabetes and hypertension. Int J Pharma Bio Sci. 2010;1(3):1-4.

7. Al-Junid SM, Ezat WP, Surianti S. Prescribing patterns and drug cost among cardiovascular patients in Hospital University Kebangsaan Malaysia. Med J Malaysia. 2007;62(1):59-65. 
8. Nwidu LL, Essien GE, N-Chris EE. Pattern of prescription in cardiovascular diseases management in Port Harcourt city, Nigeria. J Pharmacy Res. 2009;2(10):1653-8.

9. Shankar PR, Kumar P, Rana MS, Partha P, Upadyay D, Dubey AK; Morbidity profile and drug utilization in sub health post in Western Nepal. Calicut Med J. 2004:2(4):e4.

10. Gawande U, Deshmukh S, Kadam S, Potdar G, Salvitthal H. Prescription audit of patients attendees in public health facilities in Maharashtra, India with special reference to rational use of antibiotics. Int $\mathbf{J}$ Res Med Sci. 2015;3:3655-64.
11. Shah AM, Dhanani JV, Shah RB, Agrawal A, Gajjar BM. Evaluation of prescription pattern in terms of essentiality and rationality and assessment of Hospital pharmacy services utilization in tertiary care teaching rural hospital. Indian J Pharm Pract. 2010;3(2):11-5.

Cite this article as: Gari M, Varshney M, Lal S. Prescription auditing and observational study in a tertiary care hospital. Int J Basic Clin Pharmacol 2019;8:2149-52. 